\title{
Tribological characteristics of dental metal biomaterials
}

\author{
Mariusz WalczaK, KaZimierz DrozD*
}

Department of Materials Engineering, Faculty of Mechanical Engineering, Lublin University of Technology, Nadbystrzycka 36, 20-618 Lublin, Poland

\begin{tabular}{ll}
\hline ARTICLE INFO & ABSTRACT \\
\cline { 1 - 3 } $\begin{array}{l}\text { Received 14 June 2016 } \\
\text { Accepted 15 July 2016 }\end{array}$ & $\begin{array}{l}\text { The paper is a report of the examination of the tribological wear characteristics of } \\
\text { certain dental metal biomaterials. In the study, tests were undertaken on the following } \\
\text { Keywords: }\end{array}$ \\
$\begin{array}{l}\text { mear, } \\
\text { dental materials, } \\
\text { ball-on-disc test, } \\
\text { friction coefficient. }\end{array}$ & $\begin{array}{l}\text { Ti6Al4V ELI alloy (ASTM-grade 5). The tribological tests were performed in artificial } \\
\text { saliva to determine the coefficient of friction and wear factor; the traces of wear were } \\
\text { then ascertained through SEM. The significance of variations in the wear factor, was } \\
\text { subsequently assessed by the U Mann-Whitney test. The resistance to wear in the ball-on- } \\
\text { disc test under in vitro conditions was observed for the tested materials in the following } \\
\text { order: NiCrMo }>316 \mathrm{~L}>\text { Ti6Al4V }>\text { Ti grade 2. }\end{array}$ \\
\hline
\end{tabular}

\section{INTRODUCTION}

According to current literature [5,9], abrasive wear is one of the more frequent causes of damage to biomaterials. This mechanism of wear leads to reduced implant life and increased number of necessary revision treatments. Indeed, studies by Jałbrzykowski et al. [4] demonstrate that nearly $40 \%$ of all damage to dental bridges is caused by abrasive wear. The same percentage is observed for damage caused by cracking. In addition to this, almost $10 \%$ of dental bridges are damaged due to corrosive wear or tooth scale. According to Roch et al. [11], tribocorrosion processes are a significant cause of occlusal abnormalities, and they can have harmful biological effects due to an increased release of metal ions and wear products. Moreover, abrasive wear products lead to decreased mechanical properties, particularly on the contact of a tribological pair. They also intensify pain and the negative biological response of tissues. The latter effect leads to local irritation and inflammation, and, consequently, to implant failure.

During mastication, the oral cavity is under varying loads $[1,8,17]$. This generates variations in the concentration of stresses in hard tooth tissues and in prosthetic restorations, and can result in the damage of denture fixing elements or premature local wear of dental biomaterials $[13,15,16]$.

Insufficient service and cosmetic life of prosthetic products can lead to serious difficulties in both professional and personal life. Problems resulting from insufficient mastication may hamper everyday life and social contacts, as

\footnotetext{
* Corresponding author

e-mail: k.drozd@pollub.pl
}

well as cause speech defects, which, consequently, leads to, in people suffering from these problems, both a bad mental and physical state [20].

Iijima et al. [3] stress that wear factor is an essential parameter describing the tribological properties of materials used for manufacturing dental products. What is more, they draw attention to the fact that most studies in prosthodontics focus on the strength and corrosive properties of such materials while ignoring their tribological properties.

Abrasive wear is described by a frictional pair, particularly the type of materials in direct contact. The knowledge of tribological characteristics and mechanisms of wear is crucial in the design, material selection and production technology of dental biomaterials. Therefore, the aim of this study is to investigate the tribological characteristics of the following dental materials: $316 \mathrm{~L}$ steel, cp. Ti grade 2, Ti6Al4V ELI and NiCrMo alloy under in vitro conditions.

\section{MATERIALS AND METHODS}

The tests were performed on samples of metals used as dental biomaterials, i.e.: $316 \mathrm{~L}$ steel, casting alloy $\mathrm{NiCrMo}$ (with trade name Remanium CS+ manufactured by Dentaurum), technically pure titanium (ASTM-grade 2) and Ti6A14V ELI alloy - Extra Low Interstitial (ASTM-grade 5). The last two materials are manufactured by Daido Steel Co. Ltd. In this study, disk-shaped samples with a diameter of $25 \mathrm{~mm}$ and a thickness of $4 \mathrm{~mm}$ were subjected to grinding by water abrasive papers with a granularity of 300,600 and 1200 , respectively. Next, the samples underwent mechanical polishing by $3 \mu \mathrm{m}$ diamond slurry and $0.05 \mu \mathrm{m}$ oxide 
slurry. After polishing, they were cleansed with acetone and dried in hot air.

The hardness of these materials was measured under a load of $98.07 \mathrm{~N}$, using the Vickers hardness meter FV-700 with the automatic ARS 900 system from Future-Tech Corp. In the study, 6 hardness measurements were made per each batch of samples.

Wear tests were performed with a ball-on-disc tribometer manufactured by CSM Instruments, at a temperature of $37^{\circ} \mathrm{C}$, in artificial saliva $(\mathrm{pH}=5.3)$. The composition of the artificial saliva was prepared in compliance with the PN-EN ISO 10271:2012 standard [10] (Table 1). As counter samples, we used $6 \mathrm{~mm}$ diameter balls made of $\mathrm{Al}_{2} \mathrm{O}_{3}$ with a hardness $2000 \mathrm{HV}$ (manufactured by CSM Instruments). The tests were performed under a load of $5 \mathrm{~N}$, at a linear velocity of $2.51 \mathrm{~cm} / \mathrm{s}$, over a radius of $8 \mathrm{~mm}$. The total distance to measure variations in the friction coefficient was set to $100 \mathrm{~m}$. Wear was determined as a decrement in the sample's volume in the form of a wear trace produced due to the contact between the sample and the counter sample. To this end, the wear profile area of the sample was measured over the sample's circumference (at 12 measuring points) using the Dektak 150 contact profilometer manufactured by Veeco Instruments. The nose radius of the gauging point was set to $2 \mu \mathrm{m}$. Wear volume was determined as the product of the sample's mean wear area and the circumference of a circle of the wear trace produced in the ball-on-disc test. Next, a wear factor, $\mathrm{K}$, was calculated as the ratio of wear volume to the applied force and sliding distance during the test:

$$
K=\frac{\text { Wear volume }}{\text { Applied force } \times \text { sliding distance }}\left[\mathrm{mm}^{3} \mathrm{~N}^{-1} \mathrm{~m}^{-1}\right]
$$

The surface of wear trace in the materials after the tribological tests was examined using an electron scanning microscope, Phenom G2 pro (manufactured by Phenom World).

Table 1. Chemical composition of artificial saliva according to ISO 10271:2012 [10]

\begin{tabular}{|c|c|c|c|c|c|c|c|}
\hline $\mathrm{NaCl}$ & $\mathrm{KCl}$ & $\mathrm{CaCl}_{2} \cdot \mathrm{H}_{2} \mathrm{O}$ & $\mathrm{NaH}_{2} \mathrm{PO}_{4} \cdot \mathrm{H}_{2} \mathrm{O}$ & $\mathrm{Na}_{2} \mathrm{~S} \cdot 9 \mathrm{H}_{2} \mathrm{O}$ & urea & $\mathrm{H}_{2} \mathrm{O}$ & $\mathrm{pH}$ \\
\hline $0.4 \mathrm{~g}$ & $0.4 \mathrm{~g}$ & $0.795 \mathrm{~g}$ & $0.78 \mathrm{~g}$ & $0.005 \mathrm{~g}$ & $1 \mathrm{~g}$ & $1000 \mathrm{ml}$ & $5.2-5.5$ \\
\hline
\end{tabular}

\section{RESULTS AND DISCUSSION}

The values of the measured friction coefficients are given in Table 2, and are plotted as a function of distance in Fig. 1. The friction coefficients established during our study demonstrate that the highest coefficient of friction is exhibited by the pairing of $316 \mathrm{~L}$ steel and $\mathrm{Al}_{2} \mathrm{O}_{3}$ (for this pair, we also observe the highest standard deviation, i.e. \pm 0.089 ), while the NiCrMo alloy- $\mathrm{Al}_{2} \mathrm{O}_{3}$ pair demonstrated the lowest friction coefficient. The variations in the coefficient of friction as a function of distance in the analyzed cases reveal a slight tendency for the friction coefficient to increase for 316L steel; the friction coefficient gently increases with an increase in the area of contact between the surfaces. During the test, the highest stability of the friction coefficient is observed for plastic materials with the lowest hardness, i.e. NiCrMo alloy (186 \pm 7 HV10) and Ti grade 2 (193 \pm 4 HV10).
These materials probably undergo the phenomenon of "layer lubrication," which is typical of tribological tests run at high speeds. Additionally, it should be mentioned that the hardness of the nickel alloy is somewhat lower that that declared by the producer (195 HV10 according to Dentaurum). The least stable coefficient of friction is observed for $316 \mathrm{~L}$ steel $(216 \pm 4 \mathrm{HV} 10)$ and T6Al4V alloy ( $275 \pm 3$ HV10). It should be noted that, infrequently, secondary wear products enter the trajectory of direct contact between the sample and the counter-sample. This leads to a temporary increase in the coefficient of friction.

Table 2. Summary of friction coefficients determined for the tested material in contact with the counter-sample made of $\mathrm{Al}_{2} \mathrm{O}_{3}$

\begin{tabular}{|c|c|c|}
\hline Sample material & Mean friction coefficients $\mu$ & Standard deviation \\
\hline $316 \mathrm{~L}$ & 0.538 & 0.089 \\
\hline NiCrMo & 0.317 & 0.027 \\
\hline Ti6Al4V & 0.361 & 0.058 \\
\hline Ti grade 2 & 0.451 & 0.022 \\
\hline
\end{tabular}

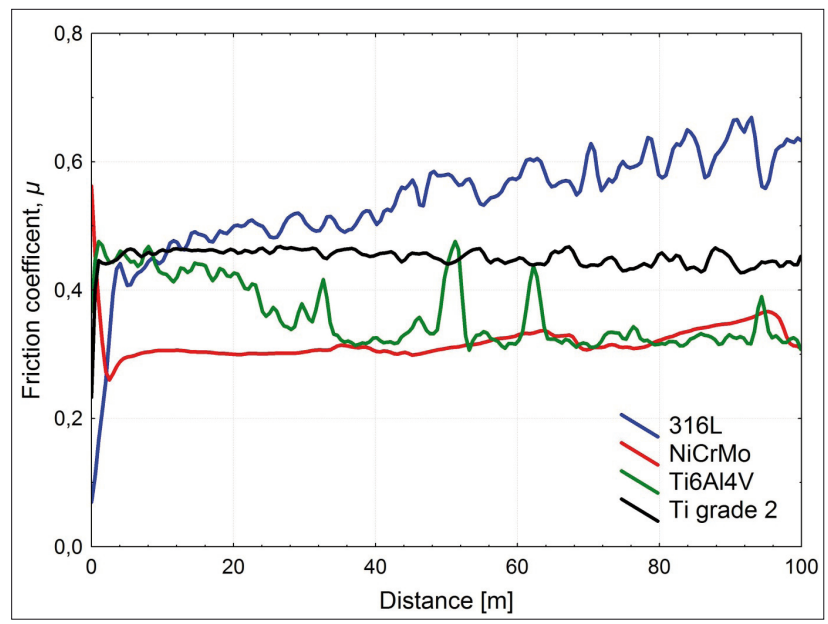

Figure 1. Curve illustrating the variations in friction coefficient vs. distance under load of $5 \mathrm{~N}$

The results of tribological tests [15] for dental NiCr alloys in artificial saliva (conducted by one of the authors of this paper at different test parameters) demonstrate that the mean friction coefficient is $\mu=0.197-0.246$. These results concur with those of Wang et al. [18], who reported the friction coefficient of $\mathrm{NiCr}$ alloys in artificial saliva to be $\sim 0.2$ in the tests conducted under a load of $4 \mathrm{~N}$ at higher speeds. The obtained friction coefficient of $\mathrm{NiCr}$ alloys is much lower that of technically pure titanium, which, according to the literature $[12,14]$, is in the range of $\mu \approx 0.45-0.72$ depending on the applied test parameters. As for Ti6Al4V alloy, Long and Rack [7] report the mean values of its friction coefficient to range at $\mu \approx 0.37-0.41$ (depending on the applied load).

Figure 2 shows the results of wear factor for metal- $\mathrm{Al}_{2} \mathrm{O}_{3}$ pairs. The highest resistance to wear under conditions of artificial saliva is observed for nickel alloy. In contrast, the highest wear is observed for technically pure titanium. In order to verify whether the obtained changes are statistically significant, an analysis based on nonparametric testing for independent tests was performed using the STATISTICA software. The results of the statistical analysis by the Shapiro-Wilk test for volume wear demonstrate that the results do 


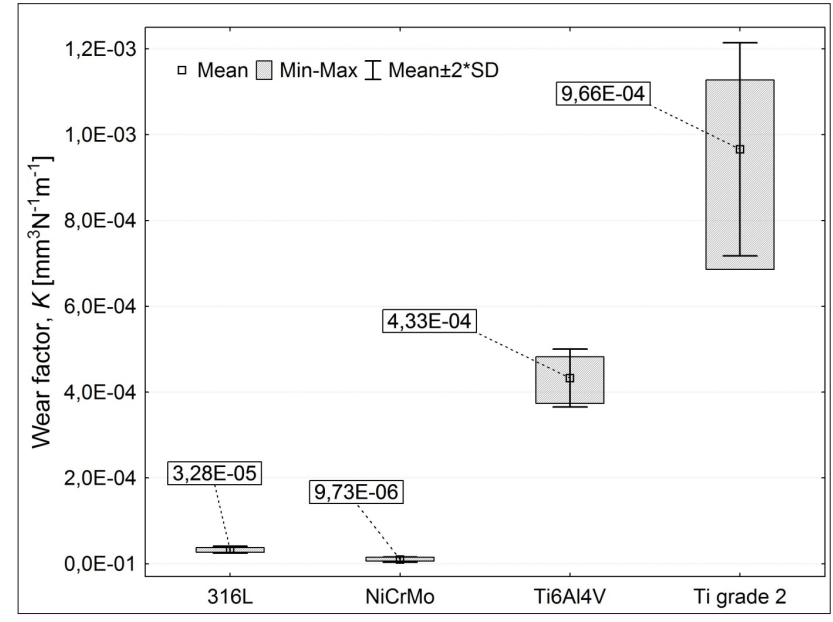

Figure 2. Diagram illustrating the wear factor $\mathrm{K}$ of the tested materials

not have a normal distribution of $\mathrm{p}<0.05$ (at $\alpha=0.05$ ). Since $\mathrm{p}<\alpha$, there is a ground to reject the hypothesis about normal distribution of the tested characteristic. Due to the fact that the values produced in wear testing do not have normal distributions, the statistic analysis of results was performed using the most powerful nonparametric test for independent tests, i.e. the U Mann-Whitney test (at $\alpha=0.05$ ). The statistic analysis results demonstrate that the differences in wear are statistically significant $(\mathrm{p}<0.05)$ in all groups of the tested materials.

The results of wear profiles analysis (Fig. 3) point towards the phenomenon of abrasive wear affecting the results. Still, the bottom of wear trace trajectory in 316L steel reveals the presence of a different mechanism of wear (it is smoother); there are no strongly visible furrows or ridging, as is the case with NiCrMo alloys, titanium and Ti6Al4V alloy. In addition, it can be observed, that in all tested materials, the edge borders of wear traces undergo swelling. Herein, the highest degree of edge border swelling and depth of wear trace are observed for technically pure titanium (which is considered to be the most plastic and ductile out of the tested materials). The degree of trace of wear depth is observed in the following order: Ti grade $2>\mathrm{Ti} 6 \mathrm{Al} 14 \mathrm{~V}>316 \mathrm{~L}>\mathrm{NiCrMo}$. Regarding the degree of edge border swelling of the wear trajectory versus the depth of wear trace, nickel-matrix alloy display the highest changes.

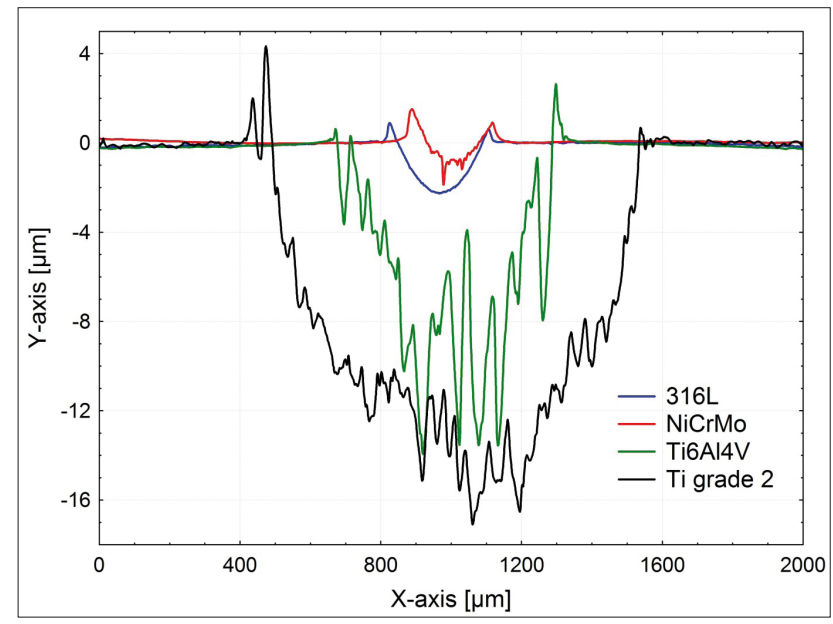

Figure 3. Examples of wear trace profiles after ball-on-disc testing
Figure 4 shows the SEM photographs of worn surfaces. Herein, it can be observed that in all examined surfaces, abrasive wear dominates. In the case of 316L steel (Fig. 4a), the process of wear was also intensified via micromachining, and the surface of the wear trace reveals the presence of the continuous scratches that are typical of steel. These are caused by free displacement of wear products along the sample-counter-sample contact path. In the case of nickel alloy (Fig. 4b), the wear process is intensified due to additional impact of loosely moving solid particles of intermetallic phases between the surfaces of the sample and the counter sample. Such a behavior leads to the higher abrasive wear of the tested alloys. The study [15] reports that the hardness of intermetallic phases in NiCrMo alloy can range from $630 \mathrm{HV}$ to $840 \mathrm{HV}$. The moving hard intermetallic phases bring about scratches on the surface of the sample or plastic deformation of fragments of the $\gamma$-Ni soft solid solution, leaving characteristic traces resembling ridging. What is more, the hard intermetallic phases form a natural obstacle for the counter sample material. The XRD analysis described in [15] indicates that in Remanium CS+ alloy, intermetallic $\mathrm{Mo}_{0,24} \mathrm{Ni}_{0,76}$ and $\mathrm{CrNi}_{2}$, as well as $\mathrm{Cr}_{7} \mathrm{Ni}_{3}$ can occur that is of a varying percentage, depending on the type of joint penetration. Similarly, Lin et al. [6] stress that fact that intermetallic phases of $\mathrm{MoNi}$ and $\mathrm{CrNi}_{2}$ can form in NiCrMo alloys.

The results of a brushing test reported by Watah et al. [19] also indicate that $\mathrm{NiCr}$ alloys undergo abrasive wear. In addition to this, Wang et al. [18] report that tribological tests on NiCrMo alloys demonstrate the impact of both adhesive and fatigue wear. However, the SEM images (Fig. 4b) do not point to fatigue wear; rather they demonstrate that the surface wear is primarily caused by abrasive wear. Still, simultaneously, adhesive phenomena could occur, this resulting from the pressing of secondary wear products into the $\gamma$-Ni solid solution soft matrix by the counter sample.

The SEM results of wear traces (Figs. $4 \mathrm{c}$ and d) for titanium and its alloy are typical of metals exhibiting high hardness and ductility. Such results reveal the presence of a plastic zone with accumulated material along the displacement of the counter sample. The dominant mechanism of wear includes abrasion and ridging. As for Ti6Al4V alloy, the samples made of technically pure titanium show more visible ridging of the wear trace (as confirmed by Fig. 3). This results from the presence of the $\beta$ phase (Ti6Al4V is a two-phase alloy, $\alpha+\beta)$, the plasticity of which is higher than that of the $\alpha$ phase, which, in turn, leads to a local increase in plastic deformation [2]. In addition, the traces of wear are characterized by micro-cracks perpendicular to the direction of moving. This points to fatigue wear. Although abrasive wear is dominant in titanium and its alloy, we can observe the occurrence of adhesive phenomena (as in the case of NiCrMo alloy) resulting from the plastic deformation of secondary wear products.

\section{SUMMARY AND CONCLUSIONS}

The knowledge of tribological characteristics and wear mechanisms of materials enable us to develop a set of comprehensive selection criteria that will be useful in designing future medical products. 
a)
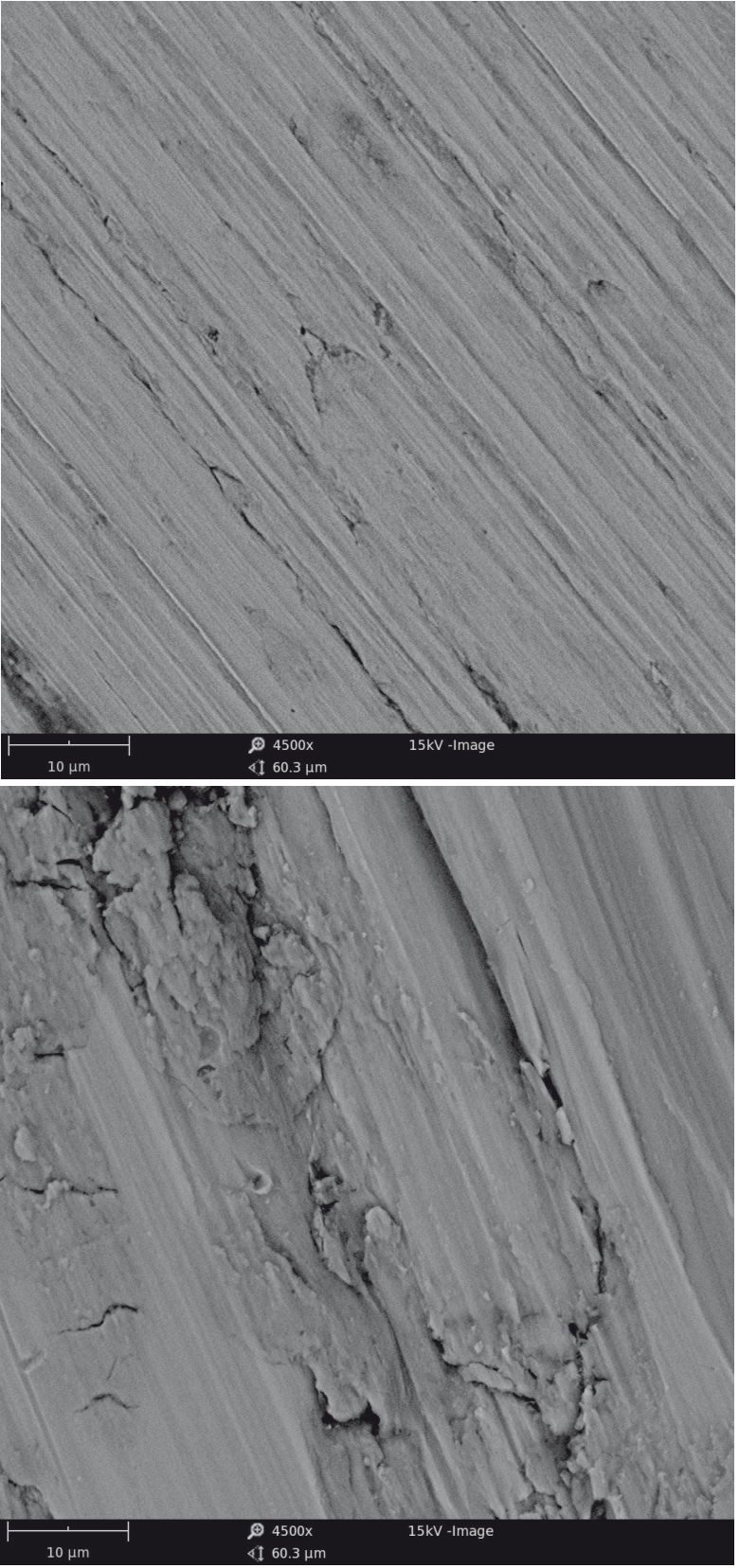

b)
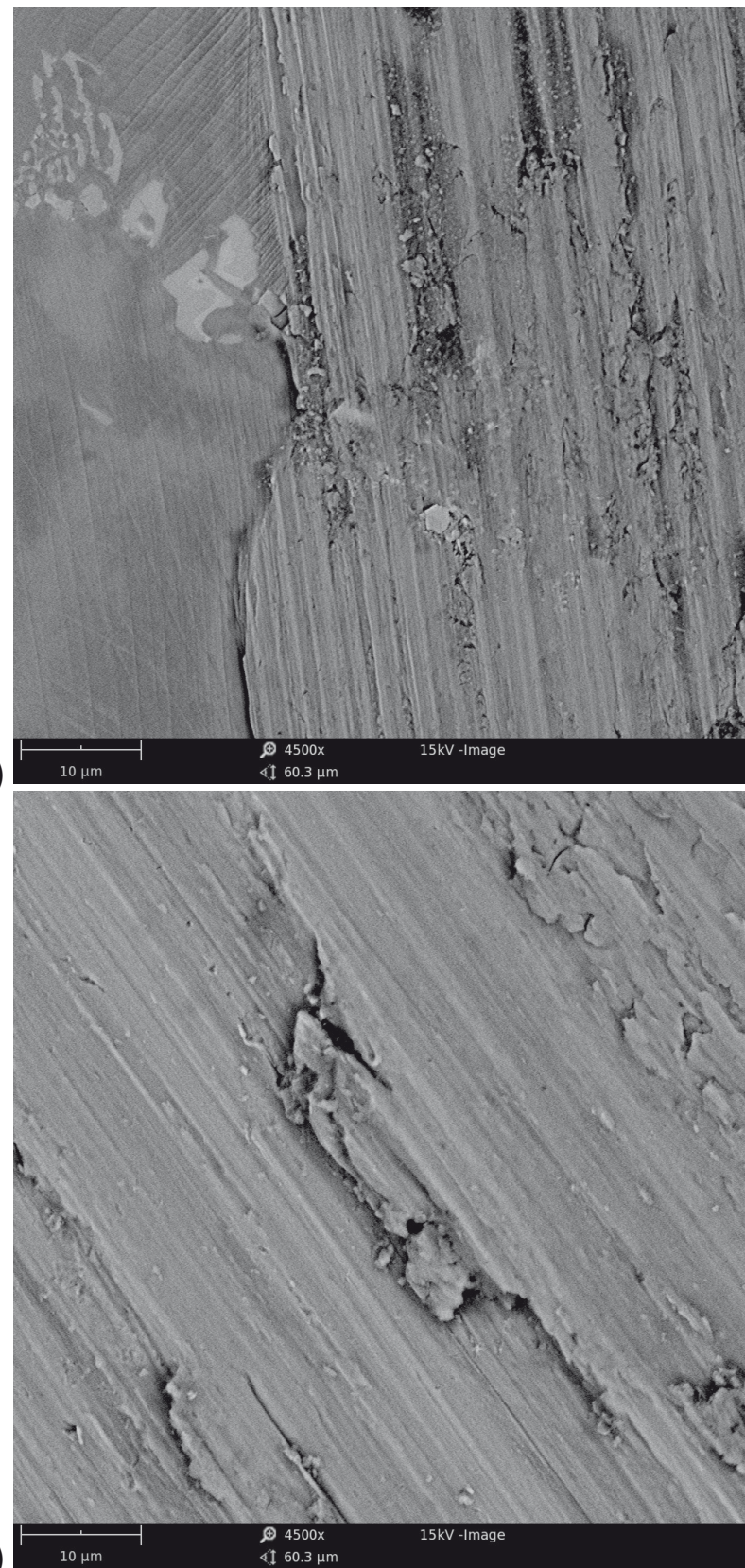

Figure 4. SEM photographs of worn surfaces: a) 316L stainless steel, b) NiCrMo alloy, c) Ti6Al4V alloy, d) cp-Ti grade 2

\section{REFERENCES}

A comparative analysis of the friction coefficients demonstrates that the lowest mean friction coefficient is exhibited by NiCrMo alloy $(\mu=0.317)$, followed by (a relatively higher value) Ti6Al4V alloy $(\mu=0.361)$, cp-Ti grade 2 $(\mu=0.451)$, and $316 \mathrm{~L}$ steel $(\mu=0.538)$. In addition, statistically significant differences can be observed with respect to wear in all the tested groups of materials ( $<<0.05$ in U MannWhitney test). The highest resistance to wear, as shown by the results of the ball-on-disc test under in vitro conditions, was observed for the tested materials in the following order: NiCrMo $>316 \mathrm{~L}>$ Ti6Al4V $>$ Ti grade 2. Generally, the tested materials exhibit an abrasive wear nature. What is more, adhesive phenomena connected with plastic deformation of secondary wear products can be observed in the case of three materials: NiCrMo, Ti6Al4V and Ti grade 2.
1. Chladek W. (2008). Biomechanika inżynierska narządu żucia. Zagadnienia wybrane. Gliwice: Wyd. Pol. Śl.; p. 169.

2. Faria A.C.L. et al.: Wear resistance of experimental titanium alloys for dental applications. J. Mech. Behav. Biomed. Mater., 4, 1873, 2011.

3. Iijima D. et al.: Wear properties of Ti and Ti-6Al-7 Nb castings for dental prostheses. Biomaterials, 24, 1519, 2003.

4. Jałbrzykowski M. et al.: Aspects of exploitation stability of selected dental prosthetic bridges. Acta Mech. Autom., 5, 54, 2011.

5. Li-Juan X. et al.: Microstructure and dry wear properties of Ti-Nb alloys for dental prostheses. Trans. Nonferrous Met. Soc. China, 19, 639, 2009.

6. Lin H.-Y. et al.: Metallurgical, surface, and corrosion analysis of $\mathrm{Ni}-\mathrm{Cr}$ dental casting alloys before and after porcelain firing. Dent. Mater., 24, 378, 2008.

7. Long M., Rack H.J.: Friction and surface behavior of selected titanium alloys during reciprocating-sliding motion. Wear, 249, $158,2001$. 
8. Milewski G. (2002). Wytrzymałościowe aspekty interakcji biomechanicznej tkanka twarda - implant w stomatologii. Kraków: Zeszyty Naukowe Politechniki Krakowskiej, seria Mechanika; p. 89.

9. Nine M.J. et al.: Wear Debris Characterization and Corresponding Biological Response: Artificial Hip and Knee Joints. Materials, 7 9802014.

10. PN-EN ISO 10271: 2012. Stomatologia - Metody badania korozji materiałów metalowych

11. Rocha L.A., Oliveira F., Cruz H.V., Sukotjo C., Mathew M.T. (2013). Bio-tribocorrosion in dental applications. Chapter in a book: Yan Y. (editor) Bio-Tribocorrosion in Biomaterials and Medical Implants. Cambridge: Woodhead Publishing Limited; pp. 223-249

12. Souza J.C.M. et al.: Simultaneous degradation by corrosion and wear of titanium in artificial saliva containing fluorides. Wear, 292-293, 82, 2012.

13. Strietzel R.: Ponowne odlewanie stopów dentystycznych. Dent. Labor., 4, 3, 2000.

14. Vieira A.C. et al.: Influence of $\mathrm{pH}$ and corrosion inhibitors on the tribocorrosion of titanium in artificial saliva. Wear, 261, 994, 2006.
15. Walczak M. (2014). Influence of the selected technological processes on durability of metal-ceramic systems used in dental prosthetics. Lublin: Published by Lublin University of Technology; p. 183

16. Walczak M., Pieniak D., Niewczas A.M.: Effect of recasting on the useful properties CoCrMoW alloy. Eksploatacja i Niezawodnosśc Maintenance and Reliability, 16, 330, 2014.

17. Walczak M., Różycki Ł.: Analiza naprężeń w twardych tkankach zębów na przykładzie dolnego siekacza $\mathrm{z}$ wykorzystaniem metody MES. Postępy Nauki i Techniki, 11, 107, 2011.

18. Wang L. et al.: Friction and wear behaviors of dental ceramics against natural tooth enamel. J. Eur. Ceram., 32, 2599, 2012.

19. Wataha J.C. et al.: Brushing-induced surface roughness of nickel-, palladium-, and gold-based dental casting alloys. J. Prosthet. Dent.,99, 455, 2008.

20. Żmudzki J. (2012). Uwarunkowania materiałowe wydolności czynnościowej całkowitych osiadających protez zębowych [Online]. Open Access Library: http://www.openaccesslibrary.com/vol10/4. pdf [2016, May 12]. 